Louisiana State University

LSU Digital Commons

Faculty Publications

Department of Geography \& Anthropology

2007

\title{
Intellectual Relations between Historical Geography and Latin Americanist Geography
}

Andrew Sluyter

Louisiana State University, asluyter@lsu.edu

Kent Mathewson

Follow this and additional works at: http://digitalcommons.lsu.edu/geoanth_pubs

\section{Recommended Citation}

Sluyter, Andrew and Mathewson, Kent, "Intellectual Relations between Historical Geography and Latin Americanist Geography" (2007). Faculty Publications. 31.

http://digitalcommons.lsu.edu/geoanth_pubs/31

This Article is brought to you for free and open access by the Department of Geography \& Anthropology at LSU Digital Commons. It has been accepted for inclusion in Faculty Publications by an authorized administrator of LSU Digital Commons. For more information, please contact gcoste1@lsu.edu. 


\title{
Intellectual Relations between Historical Geography and Latin Americanist Geography
}

\author{
Andrew Sluyter and Kent Mathewson \\ Department of Geography and Anthropology \\ Louisiana State University
}

\begin{abstract}
Content analysis of Geography in America (Gaile and Willmott 2003), which collects fortyseven chapters written by representatives of each of the specialty groups of the Association of American Geographers (AAG), reveals much about the recent intellectual structure of the discipline (Sluyter et al. 2006). One striking feature of that structure is the lack of intellectual connectivity, measured in practitioners named and publications cited, between the chapters of the Latin Americanist Specialty Group (LASG) and the Historical Geography Specialty Group (HGSG). Detailed comparison of the HGSG chapter and the Historical and Cultural Perspectives section of the LASG chapter addresses the character of that lack of connectivity, its causes, and some possibilities for its improvement.
\end{abstract}

Key words: Geography in America, historical geography, intellectual structure, multi-dimensional scaling.

\section{Resumen}

El análisis del contenido de la Geografía en América (Gaile y Willmott 2003), que recoge cuarenta y siete capítulos escritos por los representantes de cada uno de los grupos de la especialidad de la Asociación de Geografos Americanos (AAG), revela mucho sobre la estructura intelectual reciente de la disciplina (Sluyter et el al. 2006). Una característica llamativa de esa estructura es la carencia de la conectividad intelectual, mediada por los profesionales nombrados y las publicaciones citadas, entre los capítulos del grupo de la especialidad latinoamericanista (LASG) y del grupo de la especialidad de la geografía histórica (HGSG). La comparación detallada del capítulo de HGSG y de la sección histórica y cultural de las perspectivas del capítulo de LASG trata el carácter de esa carencia de la conectividad, de sus causas, y de algunas posibilidades de su mejora.

Palabras clave: Geografía en América, geografía histórica, estructura intellectual, escalando multidimensional.

It perhaps needs to be said that this brief account of the Latin Americanist historiography of the last decade should not be viewed in isolation. Too often we are marginalized as mere "regionalists" in an age that surely lacks well-trained ones. . . Our efforts, be they in historical, environmental, cultural, political, or socioeconomic also need to be seen as crucial components of each of these thematic subfields.

-From the introduction to the chapter on Latin Americanist Geography in Geography in America (Robinson et al. 2003: 691) 
analysis, regional approaches, and other significant, but more singular works.

-From the introduction to the chapter on Historical Ge-

ography in Geography in America (Colten et al. 2003: 149)

\section{Introduction}

Analysis of data that act as proxies for the intellectual relationship among geography's subdisciplines forms an essential part of the process through which geographers continuously recreate their discipline. Many examples of such analysis exist (Johnston 1983, 2003; Gatrell and Smith 1984; Goodchild and Janelle 1988; Bodman 1991; Smith 2003; Bierly and Gatrell 2004; Sluyter et al. 2006). Some consider the entire discipline; others focus on a few subdisciplines. Some emphasize quantitative methods, others qualitative. Some employ the membership rosters of the specialty groups of the Association of American Geographers (AAG); others employ citation indexes, survey questionnaires, or other databases. All help to adjudicate among competing conjectural models, often quite idealistic in conception and normative in intent, of disciplinary intellectual structure (e.g., Pattison 1964; NRC 1997). Such analyses can thereby stimulate more empirically grounded discussion about the opportunities and constraints involved in disciplinary restructuring.

The recent publication of the second edition of Geography in America (Gaile and Willmott 2003), which collects chapters written by representatives of each of the fortyseven specialty groups of the AAG, provides a particularly fruitful database for such analysis. Multi-dimensional scaling (MDS) of the name index of that edited volume reveals that the minimal connectivity between human and physical geography has come to operate more through environmental and applied than through methods or regional subdisciplines (Sluyter et al. 2006). Yet such an analysis addresses the broad features of disciplinary structure at the expense of details related to particular subdisciplines. In contrast, the following analysis of Geography in America focuses on the relationship between the subdisciplines of historical geography and Latin Americanist geography, with special reference to their lack of intellectual connectivity, its causes, and some possibilities for its improvement.

\section{Investigations of Disciplinary Intellectual Structure}

The index of names in Geography in America provides a proxy for the intellectual structure of the discipline (Gaile and Willmott 2003: 769-94; Sluyter et al. 2006). AAG specialty groups are made up of practitioners of subdisciplines that emerge out of the process through which geographers continuously recreate the intellectual structure of their discipline. For Geography in America, representatives of each specialty group wrote a chapter that summarizes research in their subdiscipline during, mainly, the 1990s (Table 1). And those authors chose which practitioners to name and publications to cite in those chapters. Each chapter, therefore, acts as a proxy for one subdiscipline, and the number of names shared among any given pair of chapters provides a measure of the degree of intellectual similarity and connectivity of the pair of associated subdisciplines.

The structure of the index of names thereby yields a proxy for disciplinary intellectual structure that combines the advantages of using AAG specialty group rosters with the advantages of using citation indexes while avoiding some of their limitations (Goodchild and Janelle 1988; Bodman 1991; Sluyter et al. 2006). Like specialty group rosters, a collection of chapters written by representatives of all the specialty groups must necessarily approach the spectrum of research interests of the AAG membership, and the structure of the name index for those chapters reflects the comprehensive structure 


\begin{tabular}{|c|c|c|}
\hline $\begin{array}{l}\text { Part } \\
\text { Chapter }\end{array}$ & $\begin{array}{l}\text { Part Title } \\
\quad \text { Chapter Title }\end{array}$ & $\begin{array}{l}\text { Equivalent } \\
\text { Term }\end{array}$ \\
\hline I & Environmental Dynamics & \\
\hline 2 & Biogeography & Biogeog \\
\hline 3 & Climate & Climate \\
\hline 4 & Cryosphere & Cryo \\
\hline 5 & Geomorphology & Geomorph \\
\hline 6 & Mountain Geography & Mountain \\
\hline II & Human/Society Dynamics & \\
\hline 7 & Cultural Geography & Cultural \\
\hline 8 & Cultural Ecology & CAPE \\
\hline 9 & Economic Geography & Economic \\
\hline 10 & Environmental Perception and Behavioral Geog. & Perception \\
\hline 11 & Historical Geography & Historical \\
\hline 12 & Political Geography & Political \\
\hline 13 & Population Geography & Population \\
\hline 14 & Sexuality and Space & Sexuality \\
\hline 15 & Socialist Geography & Socialist \\
\hline 16 & Transportation Geography & Transport \\
\hline 17 & Urban Geography & Urban \\
\hline III & Environment/Society Dynamics & \\
\hline 18 & The Human Dimensions of Global Change & $\mathrm{HD}$ \\
\hline 19 & Water Resources & Water \\
\hline 20 & Energy Geography & Energy \\
\hline 21 & Coastal and Marine Geography & Coastal \\
\hline 22 & Contemporary Agriculture and Rural Land Use & Agriculture \\
\hline 23 & Rural Development & Rural \\
\hline IV & Geographic Methods & \\
\hline 24 & Geographic Information Systems & GIS \\
\hline 25 & Remote Sensing & RS \\
\hline 26 & Cartography & Cartography \\
\hline 27 & Mathematical Models and Quantitative Methods & Quantitative \\
\hline $\mathrm{V}$ & Geographers at Work & \\
\hline 28 & Geography Education & Education \\
\hline 29 & Hazards & Hazards \\
\hline 30 & Medical Geography & Medical \\
\hline 31 & Military Geography & Military \\
\hline 32 & Aging and the Aged & Aging \\
\hline 33 & Recreation, Tourism, and Sport & Tourism \\
\hline 34 & Applied Geography & Applied \\
\hline 35 & The History of Geography & HOG \\
\hline VI & Regional Geography & \\
\hline 36 & Geography of Africa & Africa \\
\hline 37 & American Ethnic Geography & $\begin{array}{l}\text { Amer. } \\
\text { Ethnic }\end{array}$ \\
\hline 38 & American Indian Geography & $\begin{array}{l}\text { Amer. } \\
\text { Indian }\end{array}$ \\
\hline 39 & Asian Geography & Asia \\
\hline 40 & Canadian Studies & Canada \\
\hline 41 & Geography of China & China \\
\hline 42 & European Geography & Europe \\
\hline 43 & Latin American Geography & Lat. Amer. \\
\hline 44 & Russian, Central Eurasian, and East European Geog. & Russia \\
\hline VII & Values, Rights, and Justice & \\
\hline 45 & Values, Ethics, and Justice & Values \\
\hline 46 & Human Rights & Rights \\
\hline 47 & Geographic Perspectives on Women & GPOW \\
\hline 48 & Geography of Religion and Belief Systems & Religion \\
\hline
\end{tabular}

Table 1. The structure of the second edition of Geography in America, with the equivalent terms used in the text, figures, and other tables. Source: Gaile and Willmott 2003. 
of the discipline. But unlike specialty group rosters, the index of names also reveals intellectual connections to non-AAG members, both geographers and others who have influenced geographers. Also unlike specialty group rosters, but like citation indexes, the index of names is a proxy for actual participation in the ongoing recreation of the discipline's intellectual structure through publishing research, not merely intent to participate by joining a specialty group. Unlike citation indexes, however, the index of names includes a broader range of such participation, listing the authors of any article, chapter, book, abstract, presentation, or report that the chapter authors deemed to have contributed to their subdiscipline-not just those cited in journals indexed by such databases as the Social Sciences Citation Index. Also unlike analysis of citation indexes, which require that the analyst assigns each author and publication to a subdisciplinary category before measuring connectivity among them, MDS of the name index, like MDS of specialty group rosters, reveals structure inherent to the database rather than imposing structure on it. Author bias might affect whether any particular name is mentioned in any particular chapter of Geography in America, similar to the author bias intrinsic to citation indexes, but chapter authors solicited broad input from their specialty groups through listservs and special sessions at AAG conferences. Also, the size of the database neutralizes such bias: 134 chapter authors and seventy-five manuscript reviewers represent some 3.2 percent of the AAG membership in the year 2000, assuming no overlap in the two groups; the forty-seven chapters reference some 8,500 publications, again assuming no overlap, and name some 4,400 practitioners, 1,201 of them appearing in two or more chapters (Gaile and Willmott 2003, vii, xvii-xxi; Pandit 2004, 18; Johnston 2004, 1004).

Moreover, use of MDS to produce a two-dimensional visualization of the structure of the name index confirms its utility as a proxy measure of disciplinary intellectual structure (Figure 1). Any given pair of chapters, proxies for two subdisciplines, appear distant from one another in proportion to their similarity as measured by the number of shared named practitioners: chapters that share the most names tend to appear closest together; those that share the fewest names tend to appear furthest apart. Despite unavoidable distortion caused by reducing the relationships among forty-seven chapters to two dimensions, the visualization reveals various aspects of the gross intellectual structure of the discipline that will resonate with many geographers (Sluyter et al. 2006). The human and physical subdisciplines form non-overlapping groupings that approach each other along a band of subdisciplines oriented, except for the inclusion of the Remote Sensing (RS) and Cartography chapters, towards applied and/or environmental research. The other two methods subdisciplines, Geographic Information Systems (GIS) and Quantitative, form their own isolated cluster near the bottom, at far right, not far from the RS and Cartography chapters. The regional subdisciplines do not form a cluster because each has a distinct pattern of connectivity to other chapters, dominated by human geography subdisciplines, rather than to one another. Unlike the majority of regional chapters, which appear above the environmental/applied beltline of the visualization, connections to the Cultural and Political Ecology (CAPE) and Biogeography chapters draw the Latin America chapter down toward the physical geography sector of the visualization.

Nuanced understanding of the relationship of the Latin America chapter to the other forty-six, though, requires centering analysis on it. D. J. Robinson, C. Caviedes, and D. J. Keeling wrote the chapter in five sections: Introduction; Natural Environments and Interactions; Contemporary Socioeconomic, Urban, and Political Themes; Historical and Cultural Perspectives; and a conclusion titled Towards the Next Millennium (Robinson et al. 2003). They list 272 publications as references. They name 89 practitioners that also appear in at least one of the other forty-six chapters. And those shared names create 185 connections between Latin Americanist geography and other subdisciplines. 


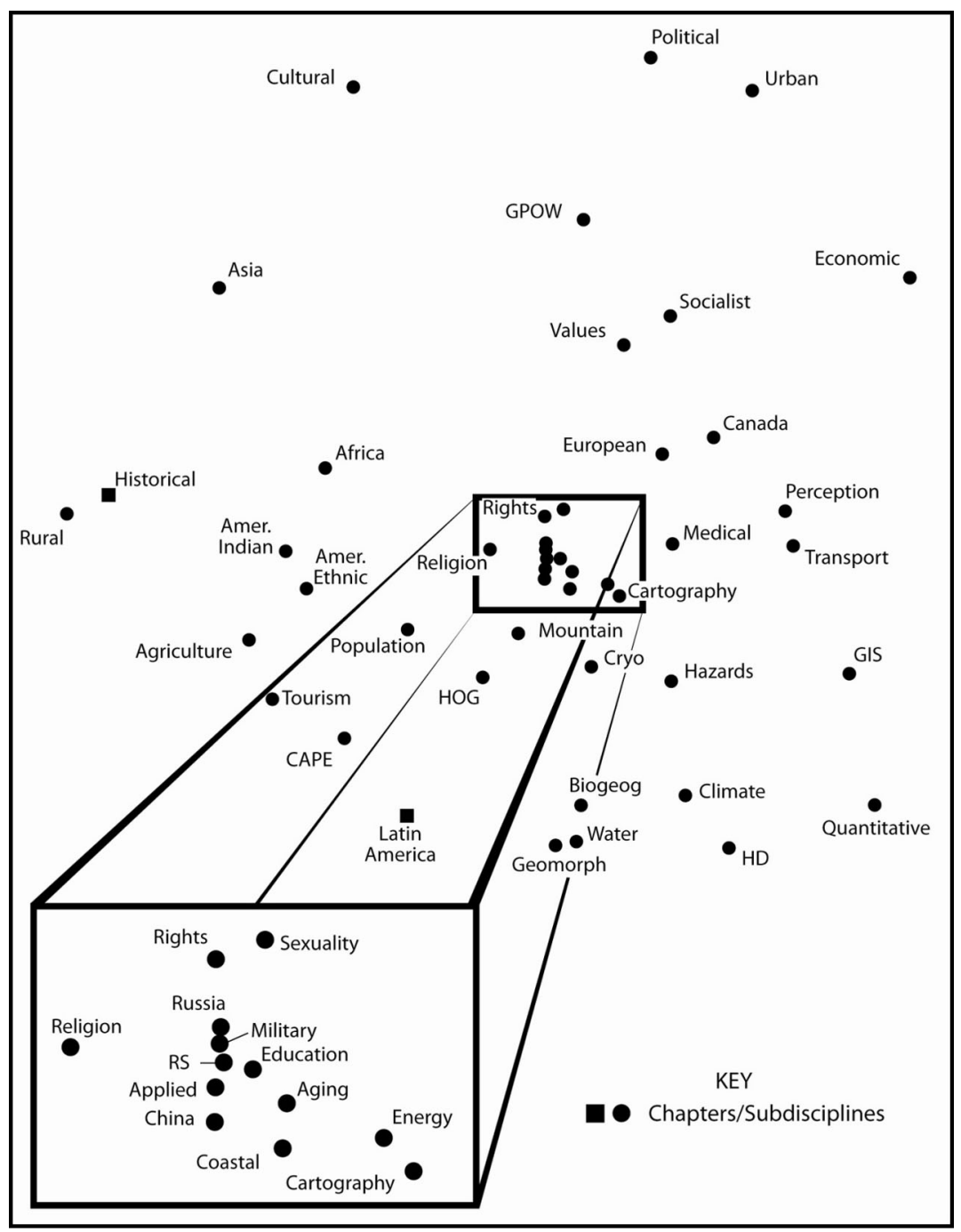

Figure 1. Two-dimensional, non-metric representation of the similarity among chapters of the second edition of Geography in America (Gaile and Willmott 2003) based on multi-dimensional scaling of its name index. Chapters, each one representing an AAG Specialty group (and thereby a geographical subdiscipline) that share many named practitioners appear relatively closer together than those that share few or none. Highly connected subdisciplines therefore tend to form clusters. The zoom box at lower left enlarges the tightly packed center of the diagram. The square symbols emphasize the Latin America and Historical chapters/subdisciplines. Source: modified by permission from Sluyter et al. 2006: Figure 1. 
Column C of Table 2 lists how many names the Latin America chapter shares with each of the others, and Column D indicates the intellectual similarity between it and them as a linear distance. Plotting those intellectual distances on polar axes with the Latin America chapter at the origin serves to visualize the relationship between it and each of the other forty-six (Figures 2 and 3). The quadrant in which each chapter appears relates to the affinity of the associated subdiscipline for one of four broad qualitative groupings: methods, regional, human, and physical geography. Environmental subdisciplines such as CAPE appear near the boundary between the human and physical quadrants; human subdisciplines with strong regional orientations such as American Indian appear near the boundary between the human and regional quadrants; and so on. That method of visualizing the structure inherent in the name index relaxes the connections among the forty-six chapters other than Latin America and, thereby, the MDS visualization's distortion of their individual relationships with Latin America but still provides some context of overall disciplinary structure.

\section{Historical and Latin America: The Case of the Missing Link}

Thus centering analysis on the Latin America chapter, as in Figure 2, reveals that half the other chapters, twenty-three out of forty-six, are 50.00 or more units distant. That the Russia, Europe, China, and Africa chapters fall so far from Latin America reiterates the results of the MDS analysis: regional subdisciplines do not interconnect, are highly dissimilar, and therefore do not cluster. The Quantitative, Cartography, and Remote Sensing chapters, three out of the four methods chapters, are similarly distant from the origin; Latin Americanists certainly employ such methods but are not well connected to the subdisciplines that focus on their refinement. Of the four physical geography subdisciplines, Climate and Cryosphere are situated far beyond Latin America's intellectual neighborhood. A whole array of human geography and some environmental and applied subdisciplines also appear distant from Latin Americanist geography, fourteen in all: Values, Transport, Sexuality, Rights, Military, Aging, Socialist, Education, Agriculture, Coastal, Economic, Religion, Energy, and Applied. None of those twenty-three distant subdisciplines have enough intellectual connectivity to Latin Americanist geography to affect much its relationship to the discipline.

Zooming in on the twenty-three chapters less than 50.00 units distant from the origin, as in Figure 3, more clearly delineates Latin Americanist geography's place within disciplinary space. Four subdisciplines fall particularly close to the Latin America chapter, each sharing more than a dozen names and therefore attaining a distance of less than 8.00 units: CAPE at 4.00, Rural at 6.25, HD (Human Dimensions) at 6.67, and Biogeography at 7.69. With the exception of Rural and Biogeography, which are 25.00 units from each other, each of the other five pair-combinations among those four chapters is a maximum of 9.09 units from the other three. In other words, from the perspective of Latin Americanist geographers, those four subdisciplines and Latin America form an intellectual cluster not readily apparent from the MDS analysis of overall disciplinary structure visualized in Figure 1.

The relationships of the Latin America chapter to those between 8.00 and 33.33 units distance invites endless analysis, but this particular paper focuses, as promised in the introduction, on the relationship with the Historical chapter written by C. E. Colten, P. J. Hugill, T. Young, and K. M. Morin (Colten et al. 2003). The two are notably distant from each other considering that the Latin America chapter contains a section titled Historical and Cultural Perspectives that names sixty-nine practitioners and cites 101 of their publications. The Historical chapter names only three out of all the practitioners named in the Latin America chapter, placing it 33.33 units from the origin, the same as the GIS 
A B

No. Chapter

CAPE

2 Rural

3 HD

4 Biogeog

5 Amer. Ethnic

6 Amer. Indian

7 Tourism

8 Water

9 Population

10 Canada

11 Cultural

12 Asia

13 Geomorph

14 Mountain

15 GPOW

16 HOG

17 Medical

18 Urban

19 GIS

20 Hazards

21 Historical

22 Perception

23 Political

24 Africa

25 Applied

26 Economic

27 Energy

28 Religion

29 RS

30 Agriculture

31 Cartography

32 China

33 Climate

34 Coastal

35 Education

36 Europe

37 Socialist

38 Aging

39 Cryo

40 Military

41 Quantitative

42 Rights

43 Russia

44 Sexuality

45 Transport

46 Values
C

Names shared with $\quad(1 / C) \times 100$

Latin America

25

$16 \quad 6.25$

$15 \quad 6.67$

$\begin{array}{ll}13 & 7.69\end{array}$

$11 \quad 9.09$

$8 \quad 12.50$

$8 \quad 12.50$

$8 \quad 12.50$

$\begin{array}{ll}7 & 14.29\end{array}$

$6 \quad 16.67$

$6 \quad 16.67$

$5 \quad 20.00$

$5 \quad 20.00$

$5 \quad 20.00$

$4 \quad 25.00$

$4 \quad 25.00$

$4 \quad 25.00$

$4 \quad 25.00$

$3 \quad 33.33$

$3 \quad 33.33$

$3 \quad 33.33$

$3 \quad 33.33$

$3 \quad 33.33$

$2 \quad 50.00$

$2 \quad 50.00$

$2 \quad 50.00$

$2 \quad 50.00$

$2 \quad 50.00$

$2 \quad 50.00$

$1 \quad 100.00$

$1 \quad 100.00$

$1 \quad 100.00$

$1 \quad 100.00$

$1 \quad 100.00$

$1 \quad 100.00$

$1 \quad 100.00$

$1 \quad 100.00$

0 “ $\infty$ "

0 " $\infty$ "

0 " $\infty \infty "$

$0 \quad$ " $\infty "$

0 “ $\infty "$

0 “ "

0 “ $\infty$ "

0 " $\infty$ "

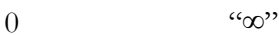

Table 2. The number of names shared between the Latin American chapter and all others in Geography in America (Gaile and Wilmott 2003). Source: see text. 


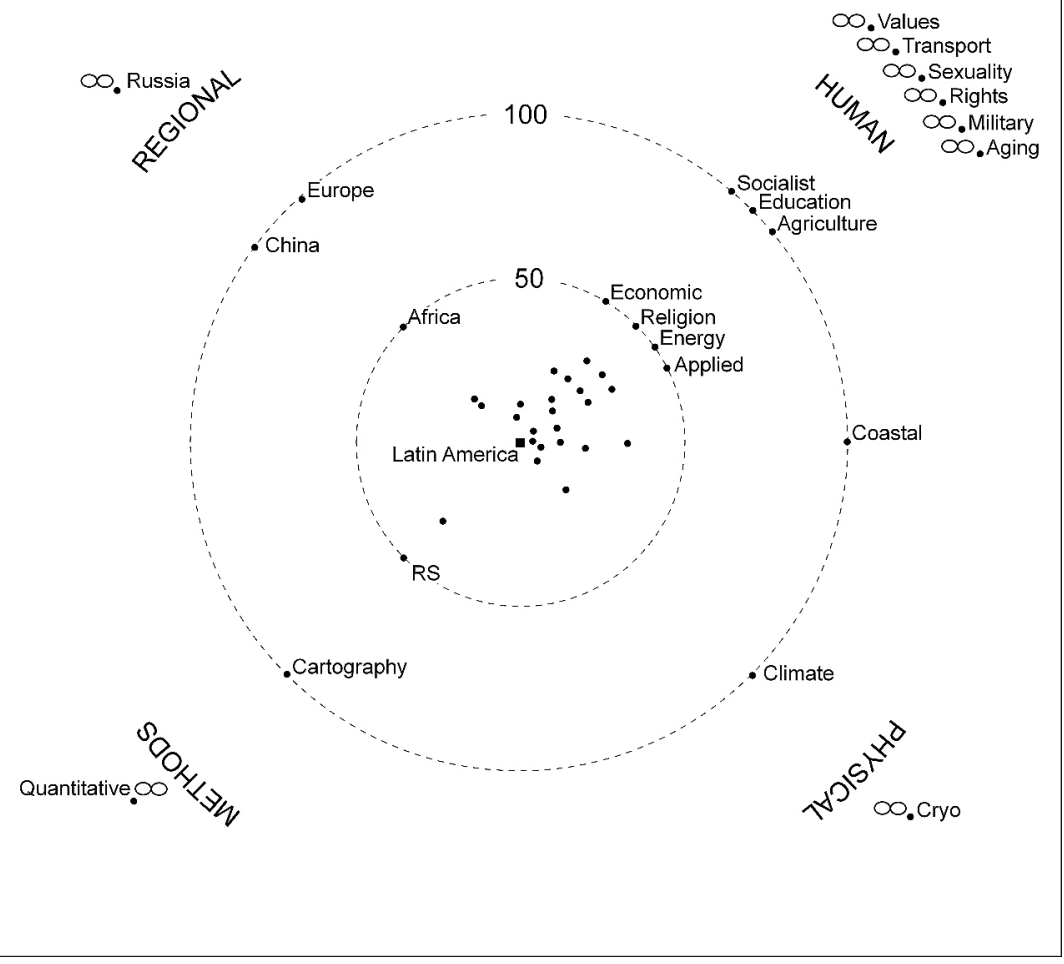

Figure 2. Intellectual distance between the Latin America chapter (square symbol) and all others (round symbols) in Geograpby in America (Gaile and Willmott 2003). Source: data from Table 2.

chapter. The Cultural chapter, at 16.67 units, is twice as close. Even a physical geography chapter, Geomorphology, is closer, only 20.00 units distant.

Understanding that seemingly great intellectual distance between the Latin America and Historical chapters requires elaboration of the character of that lack of connectivity through a content analysis of the relevant sections of Geography in America. The Historical and Cultural Perspectives section of the Latin America chapter yields a list of sixty-nine Latin Americanist historical and cultural geographers and 101 of their publications that appeared during the 1990s. The relationship between the two chapters hinges on which of the names and publications on that list are shared with the Historical chapter, or not, and the reasons why. That list of sixty-nine named practitioners provides a reasonable roster of Latin Americanist historical geographers. Some of those named might well conduct more cultural-contemporary than cultural-historical or other types of historical research. Some might focus on pre-colonial rather than colonial or postcolonial times. And other sections of the Latin America chapter cite some historical research that does not appear in the Historical and Cultural Perspectives section. The list of sixty-nine practitioners, however, amounts to twenty-three times as many as the Historical chapter names, so they and their 101 publications provide a usable list of Latin Americanist 


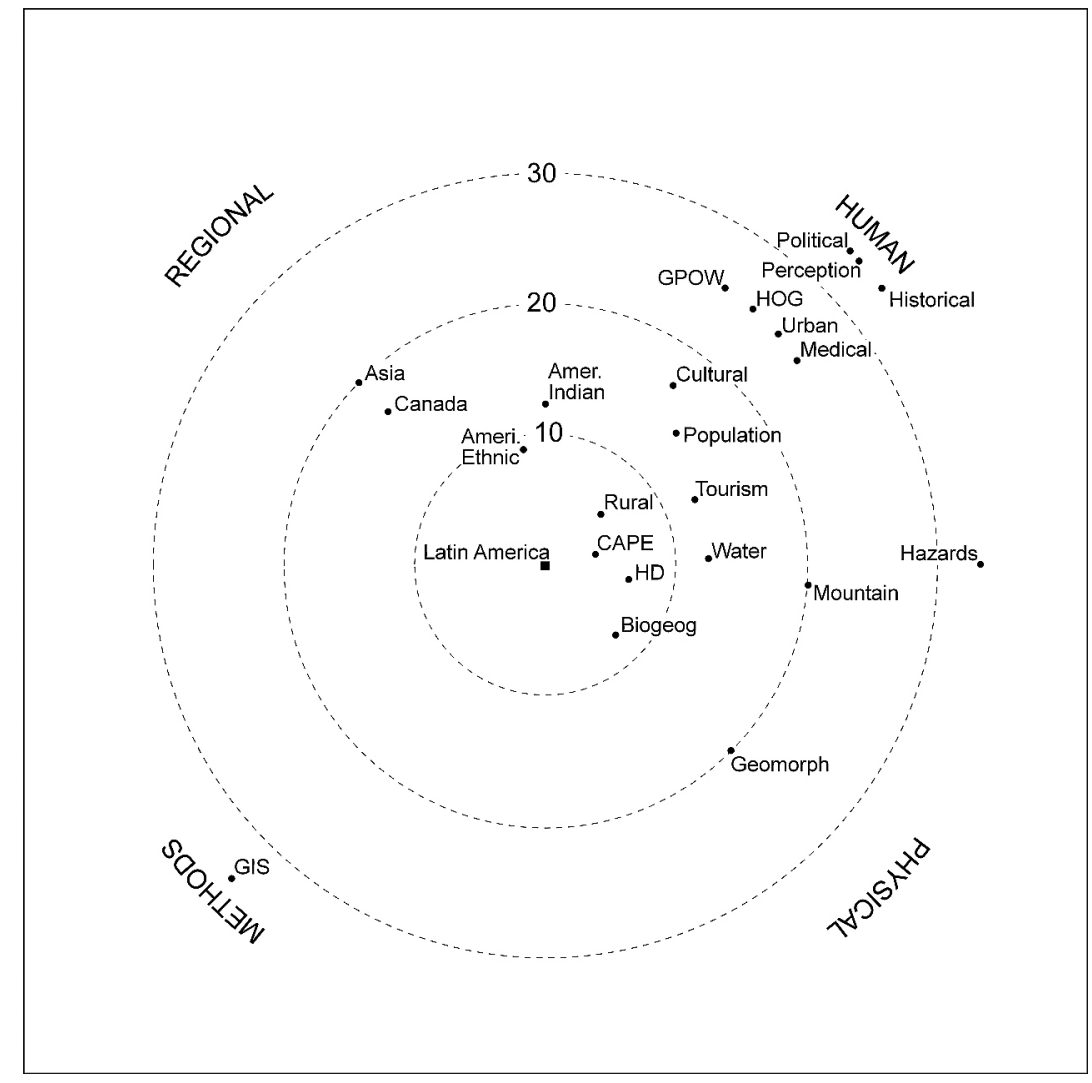

Figure 3. Intellectual distance between the Latin America chapter (square symbol and the closest twenty-three others (round symbols) in Geography in America (Gaile and Willmott 2003). Source: data from Table 2.

historical geographers and their articles, books, and chapters published during, mainly, the 1990s.

The three of those sixty-nine names (4.4 percent) that appear in the Historical chapter do so in its Environmental Historical Geography section, and no names from any other section of the Latin America chapter appear in the Historical chapter. C. Boone appears for his research on flood control in Montreal, D. Gade for his work on weeds in Vermont, and A. Sluyter for his on livestock introductions into New Spain. The Latin America chapter, however, mentions Boone and Gade for entirely different research projects than on Montreal and Vermont, respectively for work on Rio de Janeiro and the Andes. Conversely, Sluyter appears in both chapters for research on the environmental history of New Spain, both chapters even citing the same 1996 Geographical Review article. Additionally, the Latin America chapter mentions him for his research on pre-colonial agricultural landscapes, but the Historical chapter does not. So while the two chapters share a total of three names, the Historical chapter names only one in the role of a practitioner of Latin Americanist historical geography and cites only one of his publications in common with the Latin America chapter.

The Historical Chapter does have a section that explicitly addresses regional his- 
torical geography. Yet the closest the single paragraph on "regional approaches" within that section comes to citing Latin Americanist historical geography is a reference to research on the "Hispano homeland" of the US Southwest (Colten et al. 2003: 154-55).

That lack of attention to the Latin American region contrasts markedly with the Historical chapter in the first edition of Geography in America, written in the late 1980s, which includes a section titled The Historical Geography of Latin America (Earle et al. 1989: 172-74). That section states that the "historical geography of Latin America has a long tradition in the AAG, maintained over the decades by some of the Association's most-distinguished members," and names nineteen such practitioners (Earle et al. 1989: 172). Eight of them appear among the forty-four Latin Americanist historical geographers named in the Historical Antecedents section of the Latin America chapter in that same first edition of Geography in America (Robinson 1989: 490-93). That level of connectivity would have placed the Historical chapter only 12.5 units from the Latin America chapter, much nearer the origin than its present peripheral position, closer even than the Cultural chapter.

\section{Probable Causes}

The basic reason for the lack of connectivity between the Historical and Latin America chapters in the second edition of Geography in America thus seems clear enough. The Historical chapter fails to name most of the many practitioners of Latin Americanist historical geography and, of the three named, names two for their research projects in Canada and New England rather than for those in Latin America. In contrast, because Latin Americanist historical geography is a regional variant of historical geography in general, the Latin America chapter cannot logically be expected to reference research on, for example, the historical geography of North America or any other region.

Yet the authors of the Historical chapter give no reason for such omission of Latin Americanists, and personal bias does not seem to pertain. The four authors represent 1.3 percent of the 310 members of the Historical Geography Specialty Group (HGSG) in 2000, were chosen by that membership to represent its breadth, solicited broad input while drafting the chapter, circulated drafts for feedback, presented a draft at the 1999 Honolulu meeting of the AAG, subjected it to blind review and editorial critique, and revised accordingly (Gaile and Willmott 2003: vii; Pandit 2004: 18; Craig Colten, personal communications of $06 / 29 / 05$ and $09 / 12 / 06$ ). The probable cause or causes of the near total omission of references to Latin Americanist historical geography thus remain uncertain.

One possibility is that Latin Americanist historical geographers publish in journals so obscure to the authors of the Historical chapter that they did not realize the existence of that literature. Certainly, many of the 101 publications cited in the section on Historical and Cultural Perspectives in the Latin American chapter appear in outlets regionally specific to Latin Americanist research, either disciplinary journals such as the Journal of Latin American Geography and its predecessor the CLAG Yearbook or interdisciplinary journals such as the Colonial Latin American Review. Yet many appear in disciplinary outlets that all geographers presumably peruse on a regular basis: five in the Geographical Review; six in the Annals of the Association of American Geographers; and one in the Transactions of the British Institute of Geographers; although none in the Professional Geographer or Area. In addition to the twelve that appear in those major disciplinary journals, three more occur in one of the main subdisciplinary journals for historical geographers: the Journal of Historical Geography. None of the 101 is from Historical Geography, however, the other main subdisciplinary journal. 

A
B
C
D

No. Chapter

Names shared with Historical

1 Cultural

30

2 Amer. Ethnic

22

C) $\times 100$

19

3.33

Canada

15

4.55

5.26

5 Political

15

6.67

Urban

6.67

GPOW

6.67

15

7.14

8 Tourism

14

8.33

Agriculture

9.09

9.09

Geomorph

10.00

HOG

10.00

Perception

11.11

Religion

11.11

Values

11.11

Water

14.29

GIS

16.67

Asia

16.67

Biogeog

16.67

16.67

16.67

Rural

20.00

Coastal

20.00

Economic

20.00

Europe

20.00

HD

20.00

Mountain

25.00

CAPE

25.00

33.33

33.33

33.33

33.33

50.00

50.00

50.00

50.00

100.00

100.00

100.00

100.00

100.00

100.00

" $\infty$ "

“ $\infty "$

" $\infty$ "

" $\infty "$

46 Energy

Table 3. The number of names shared between the Historical chapter and all others in Geography in America (Gaile and Willmott 2003). Source: see text. 
Moreover, many of the monographs and edited volumes in which Latin Americanist historical geographers published their research received book reviews in those same major geography and historical geography journals during the 1990s. A search using Web of Science-which incorporates the Science Citation Index Expanded, Social Sciences Citation Index, and the Arts and Humanities Citation Index-of the issues of those journals dating to the 1990s found many such reviews of the books cited in the section on Historical and Cultural Perspectives in the Latin American chapter (http://isi01. isiknowledge.com; accessed on 06/23/05). Six of them appeared in the Annals of the Association of American Geographers, three in the Professional Geographer, one in Area, five in the Geographical Review, and five in the Journal of Historical Geography (but none in the Transactions of the British Institute of Geographers). Additionally, more such book reviews might have appeared in Historical Geography, but the Web of Science does not index that journal. Those figures exclude several book reviews published after 1999 because the authors of the Historical chapter submitted their manuscript in 1999, making only minor revisions in October 2001 (Craig Colten, personal communication of 06/29/05).

Another possible cause is that historical geographers of the US and Canada so dominate the HGSG that the chapter authors drawn from among its membership simply do not relate to the historical geography of other regions. In other words, "official" historical geographers - members of the HGSG—do not think of historical geography focused on Latin America, Asia, Africa, or any other region outside of the US and Canada as being historical geography. Nor, perhaps, do they think of themselves as regionalists: North Americanist historical geographers.

To analyze that possibility, column C of Table 3 lists how many names the Historical chapter shares with each of the others, including all nine regional chapters; and Column D then records intellectual similarity as a linear distance. Among the most similar are the three chapters with a strong regional affinity for the US and Canada: American Ethnic, American Indian, and Canada. Of the other six regional subdisciplines, Asia is 16.67 units distant, Europe 20.00, Africa and Latin America 33.33, and Russia 50.00, with China at "infinity" (" $\infty$," although strictly speaking the inverse of zero does not equal infinity). The Canada chapter does have a section that focuses on historical geography_Canada's Regions: Cultural and Historical Perspectives-possibly explaining its proximity to the Historical chapter. Yet the distant Latin America and China chapters also have similar sections on historical research. Proximity to the Historical chapter thus seems more related to doing US or Canadian historical geography than to doing historical geography per se.

Analysis of the high-profile special issue of the Annals of the Association of American Geographers that marked the quintcentennial of the first voyage of Christopher Columbus also supports the possibility that the members of the HGSG do not perceive Latin Americanist historical geography to be bona fide historical geography. That special issue on a classic historical geographical theme covers the Americas from Canada to South America (Butzer 1992). The Historical chapter mentions the issue title, "The Americas Before and After 1492," and three of the article authors (Colten et al. 2003: 154). The Latin America chapter names the editor and seven of the article authors, all of them Latin Americanists, of course. If the Historical chapter had also named those eight, the number of connections between the two chapters would be ten instead of three, yielding an intellectual distance of only 10.00 units instead of 33.33. Yet the Historical chapter names only one of the same practitioners named in the Latin America chapter, Gade, the others seemingly considered to be something other than historical geographers-perhaps cultural or political ecologists, (pre)historical geographers, or "mere 'regionalists" (Robinson et al. 2003: 691). 
Feedback from the lead author of the Historical chapter further supports this probable cause. He has suggested that "we sought, to some extent, to try to avoid overlapping with the [Latin America] chapter" (Craig Colten, personal communication of 09/12/06). The implicit assumption, of course, is that "we" historical geographers are North Americanists and that the overlaps to avoid should be with regions outside of North America, not with the Canada chapter and not with American Ethnic or American Indian, two other strongly North Americanist topical chapters.

A third possible cause of the omission is that the authors of the Historical chapter simply did not recognize the names of the practitioners of Latin Americanist historical geography when they scoured the tables of contents and book reviews of geography journals dating to the 1990s and therefore associated only one out of sixty-nine with the literature of historical geography. Several databases could potentially address that issue but their analysis would constitute an additional research project. Nonetheless, some exploratory analysis suggests a lack of institutional overlap between Latin Americanist and North Americanists historical geographers, at least at the institutional scale of the AAG.

The membership rosters of AAG specialty groups provide insight into institutional overlap at the scale of the AAG. Goodchild and Janelle (1988) last analyzed that database by using the 1984 membership rosters to determine the degree of similarity among specialty groups. At that time, the AAG had 5,708 members, the HGSG had 342 members, and the Latin Americanist Geography Specialty Group (LASG) had 202 members, both therefore being medium-sized specialty groups (Goodchild and Janelle 1988; Pandit 2004: 18). So little overlap occurred in their membership rosters in 1984, however, that linkage analysis did not reveal any sort of connection between the LASG and the HGSG, even a weak one of a few (defined as less than 15) joint members (Goodchild and Janelle 1988: 11-15). More recently, in 2000, as the editors of the second edition of Geography in America were compiling the chapters of that volume, the AAG had 6,497 members, the HGSG had 310 members, and the LASG had 257, both still medium-sized specialty groups albeit with some shrinkage of the HGSG and growth of the LASG (Pandit 2004: 18). Determination of the present overlap in their membership rosters awaits a repeat of that aspect of the 1988 Goodchild and Janelle study, but given the 27.2 percent growth in the LASG, if a significant number of its new members had also joined the HGSG since 1984, its size would presumably also have grown rather than declined by 9.4 percent.

The programs of the AAG annual meetings provide a potentially complementary database, especially regarding co-sponsorship of sessions by the HGSG and the LASG. Demonstrating that potential and giving some indication of what the results of a thorough study would be, a search of the on-line program for the 2005 Denver meeting found only a single session co-sponsored by HGSG and LASG (http://communicate. aag.org/eseries/aag_org/program; accessed on 06/23/05). The 2006 Chicago meeting also had only a single session co-sponsored by HGSG and LASG (http://communicate. aag.org/eseries/aag_org/program; accessed on 04/25/06). Moreover, according to the program of the 1999 Honolulu meeting, the editors of Geography in America organized special sessions that year for the presentation of pre-publication versions of the fortyseven chapters. The authors of the Historical chapter presented on 24 March; those of the Latin America chapter presented the next day. So the opportunity for mutual interaction and feedback certainly existed. But the authors of the Historical chapter do not seem to have attended the Latin America paper to learn of the many historical geographers working in that region. Nor do the authors of the Latin American chapter seem to have attended the Historical paper to point out the omission. 
To assess the degree of institutional overlap at the scale of individual departments, the annual AAG guide to programs in North America provides a potentially useful database. Perusal of the 1999-2000 guide for some of the departments with well established Latin Americanist programs indicates that practitioners of each subdiscipline are departmental colleagues. At the University of Texas at Austin, the late T. G. Jordan was a colleague of W. E. Doolittle and K. W. Butzer, the first appearing in the Historical chapter and the second two among the sixty-nine named in the Historical and Cultural Perspectives section of the Latin America chapter. Similarly, D. W. Meinig and D. J. Robinson have long been colleagues at Syracuse University. R. C. Harris and A. H. Siemens spent most of their careers together at the University of British Columbia. And C. E. Colten, D. DeLyser, and K. Mathewson are colleagues at the Louisiana State University, with recently departed (W. V. Davidson in 2001 and C. Earle in 2003) and arrived (A. Sluyter in 2003) colleagues also reflecting that institutional cohabitation of North Americanist and Latin Americanist historical geographers.

The fourth possibility, the final one considered herein, relates to the clustering of the Latin America, CAPE, Rural, HD, and Biogeography chapters around the origin. That pattern revealed by the quantitative analysis seems related to the persistent impact of C. O. Sauer and his doctoral student J. J. Parsons of the University of California at Berkeley on each of those subdisciplines (despite their passing away in 1975 and 1997, respectively). Sauer's and Parson's similar research interests are echoed in the five chapters: rural aspects of development and environment in Latin America, particularly related to changes in settlement, agriculture, and vegetation. The CAPE and HD chapters do not mention Sauer or Parsons, seemingly because of the focus on reviewing research in the 1990s, but the Latin America, Biogeography, and Rural chapters nonetheless mention one or both of them. Moreover, the academic genealogy of the practitioners that create most of the connectivity within the cluster reflects the legacy of Sauer and Parsons (Brown and Mathewson 1999). Of the five names that appear in the Latin America as well as at least three of the other four chapters, two are students of Parsons (and therefore students of a student of Sauer). One is a student of a Parsons student, and another is a student of a student of a Parsons student. The one practitioner named in all five chapters clustered around the origin is a student of a student of a student of a Parsons student.

The equally enduring impact of Sauer on historical geography-for example, his 1941 Foreword to Historical Geography enjoys canonical status in that subdisciplinemakes the intellectual distance between the Historical chapter and the cluster around the origin all the more striking but also suggests that the fourth possible cause might be "dynastic divergence." Around 1940, when Sauer was writing the Foreword to Historical Geography and unambiguously embracing historical research as his preferred approach, his doctoral students included Parsons, Robert Bowman, Henry Bruman, George Carter, Andrew H. Clark, Webster McBryde, Dan Stanislawski, and Robert C. West. All went on to make significant contributions to Latin Americanist cultural and historical geography-except Clark, who opted for a dissertation on New Zealand. While Parsons remained at Berkeley to continue Sauer's research on environmental topics and native peoples south of the border as well as his prolific production of Ph.D.s, Clark went to the University of Wisconsin-Madison to found what became known as the Wisconsin or Clark School of Historical Geography. It also produced a dynasty of many Ph.D.s, but they focused on the Europeans who colonized temperate latitudes, especially the US and Canada, and until recently largely avoided topics involving the environment and, especially, the native peoples whom Europeans colonized (Sluyter 2001).

The HGSG thus seems dominated by the Clark School of Historical Geography 
and eschews, just as Clark did while a student at Berkeley, the region and topics chosen by most of Sauer's other students and, subsequently, those of Parsons. As the authors of the Historical chapter phrase that bias against research on the colonized and regions beyond North America, this "essay will compress the discussion of Native Americans in a section on landscape analysis, regional approaches, and other significant, but more singular works" (Colten et al. 2003: 149). Elaborating on that possibility, the last considered here, would require an entirely additional research project, one oriented toward qualitative historical analysis of archival sources such as the Carl O. Sauer Papers (Bancroft Library, University of California at Berkeley), the Andrew Hill Clark Fonds (Public Archives of Nova Scotia), and the Andrew H. Clark Papers (Memorial Library, University of Wisconsin-Madison) rather than quantitative content analysis of publications such as Geography in America.

\section{The Promise of Rehabilitation}

The analysis reveals that historical geographers of the US and Canada so dominate the HGSG, and therefore the writing of its chapter in the second edition of Geography in America, that it largely ignores the historical geography of other regions such as Latin America. Testing that finding against a much broader review of individual books and articles that North and Latin Americanist historical geographers have published remains a necessary task, and it might well reveal greater intellectual connectivity than does the forgoing analysis. Nonetheless, between the 1989 and 2003 editions of Geography in America, the intellectual distance between the Historical and Latin America chapters nearly tripled, from 12.50 to 33.33. Latin Americanist historical geographers certainly publish books and articles in journals that should be highly visible to all historical geographers and are, in fact, departmental colleagues with historical geographers of the US and Canada. But at the institutional level of AAG specialty groups, little interaction takes place between HGSG and LASG members. Possibly, that separation has roots several generations old, a "dynastic divergence" between the academic progeny of Parsons and Clark that continues to the present.

Yet rather than promote changing the name of the HGSG to the Historical Geography of North America Specialty Group, this analysis will hopefully help rekindle connections between the HGSG and LASG, between North Americanist and Latin Americanist historical geographers. If more Latin Americanist historical geographers would more actively participate in the HGSG-and some have served on its board, even as its chair-the entire subdiscipline of historical geography would benefit. In institutional terms alone, Latin Americanist and other non-North Americanist historical geographers who join the HGSG would reverse the apparent contraction of its membership roster (Pandit 2004: 18). In intellectual terms, greater trans-regional awareness within the HGSG would save the effort of reinventing methods, concepts, and models (Sluyter 1997). And the HGSG, when sponsoring major reviews of the historical geography literature such as the Historical chapter in Geography in America, could include rather than exclude research on Latin America and other regions, thus stimulating comparisons of similar processes, such as colonization, across regions and from a global perspective (Sluyter 1999).

Optimistically, broader social and intellectual processes might already be catalyzing such reconnection. The relatively strong connections between the American Ethnic chapter and both the Historical (4.55) and the Latin America (9.09) chapters is one indication of such processes. That proximity relates to an aspect of globalization, namely the expanding proportion of Latinos in the North American population and their persistent connections to communities in Latin America through remittances and circular migration. Latin Americanists are thereby drawn to research in North America and vice versa. 
A second indication might be the proximity of the American Indian chapter to both the Historical (5.26) and the Latin America (12.50) chapters. That connectivity seems to represent the growing influence of (post)colonial theory among North Americanist historical geographers, stimulating research on the colonized native peoples that complements a long-standing preoccupation with European colonizers and thus reworking intellectual terrain long cultivated by Latin Americanist historical geographers (Sluyter 1997, 2001). That both the American Ethnic and American Indian specialty groups have changed their names since publication of the second edition of Geography in America in order to be more inclusive- to the Ethnic Geography and Indigenous Peoples specialty groups, respectively-should stimulate even greater connectivity through those channels between all the regional variants of historical geography, including those regionalists who study North America.

\section{Acknowledgments}

We thank Clifford ("Dupe") Duplechin Jr. for drafting Figure 1 and the three anonymous reviewers for their extremely helpful feedback. Our friend and colleague Craig Colten provided extremely valuable insider information through many discussions as well as critically reviewing the penultimate draft.

\section{References}

Bierly, G. D. and Gatrell, J. D. 2004. Structural and compositional change in geography graduate programs in the United States: 1991-2001. The Professional Geographer 56: 337 44.

Brown, S. S. and Mathewson, K. 1999. Sauer's descent? Or Berkeley roots forever? Association of Pacific Coast Geographers Yearbook 61: 137-57.

Bodman, A. R. 1991. Weavers of influence. Transactions of the Institute of British Geographers 16: 21-37.

Butzer, K. W., guest ed. 1992. The Americas Before and After 1492: An Introduction to Current Geographical Research. Annals of the Association of American Geographers 82: 343-568.

Colten, C. E., Hugill, P. J., Young, T., and Morin, K. M. 2003. Historical Geography. In. Geography in America at the dawn of the $21^{\text {st }}$ century, G. L. Gaile and C. J. Willmott (eds.), pp. 149-63. New York: Oxford University Press.

Earle, C. et al. 1989. Historical Geography. In Geography in America, G. L. Gaile and C. J. Willmott (eds.), pp. 156-91. Columbus, OH: Merrill.

Gaile, G. L. and Willmott, C. J. (eds.) 1989. Geography in America. Columbus, OH: Merrill.

. (eds.) 2003. Geography in America at the Dawn of the 21 ${ }^{\text {st }}$ Century. New York:

Oxford University Press.

Gatrell, A. C. and Smith, A. 1984. Networks of relations among a set of geographical 
journals. Professional Geographer 36: 300-307.

Goodchild, M. F. and Janelle, D. G. 1988. Specialization in the structure and organization of geography. Annals of the Association of American Geographers 78: 1-28.

Johnston, R. J. 1983. Resource analysis, resource management and the integration of human and physical geography. Progress in Physical Geography 7: 127-46.

2003. Geography: A different sort of discipline? Transactions of the Institute of British Geographers 28:133-41.

NRC (National Research Council). 1997. Rediscovering Geography: New Relevance for Science and Society. Washington, DC: National Academy Press.

Pandit, K. 2004. Geography's human resources over the past half-century. Professional Geographer 56: 12-22.

Pattison, W. D. 1964. The four traditions of geography. Journal of Geography 63: 211-16.

Robinson, D. J., Caviedes, C., and Keeling, D. J. 2003. Latin American Geography. In Geography in America at the dawn of the $21^{\text {st }}$ century, G. L. Gaile and C. J. Willmott (eds.), pp. 691-706. New York: Oxford University Press.

Robinson, D. J. 1989. Latin America. In Geography in America, G. L. Gaile and C. J. Willmott (eds.), pp. 488-505. Columbus, OH: Merrill.

Sauer, C. O. 1941. Foreword to historical geography. Annals of the Association of American Geographers 31: 1-24.

Sluyter, A. 1997. On excavating and burying epistemologies. Annals of the Association of American Geographers 87: 700-2.

. 1999. The Making of the Myth in Postcolonial Development: MaterialConceptual Landscape Transformation in Sixteenth-Century Veracruz. Annals of the Association of American Geographers 89: 377-401.

2001. Colonialism and landscape in the Americas: Material/conceptual transformations and continuing consequences. Annals of the Association of American Geographers 91: 410-28.

Sluyter, A., Augustine, A. D., Bitton, M. C., Sullivan, T. J., and Wang, F. 2006. The recent intellectual structure of geography. Geographical Review 96.

Smith, J. S. 2003. Cultural geography: A survey of perceptions held by cultural geography specialty group members. Professional Geographer 55: 18-30. 